\title{
ОСОБЛИВОСТІ ДІЯЛЬНОСТІ СЕРЕДНЬОГО ТА МАЛОГО БІЗНЕСУ В УМОВАХ ПАНДЕМIÏ COVID-19
}

\section{FEATURES OF MEDIUM AND SMALL BUSINESS ACTIVITY IN THE CONTEXT OF A PANDEMIC COVID-19}

\author{
Васюта Вікторія Борисівна \\ кандидат технічних наук, доцент, \\ Національний університет «Полтавська політехніка імені Юрія Кондратюка» \\ ORCID: https://orcid.org/0000-0002-7469-3968 \\ Житник Оксана Миколаївна \\ студентка, \\ Національний університет «Полтавська політехніка імені Юрія Кондратюка» \\ ORCID: https://orcid.org/0000-0001-5397-8238 \\ Vasiuta Viktoriia, Zhytnyk Oksana \\ National University «Yuri Kondratyuk Poltava Polytechnic»
}

\begin{abstract}
Стаття присвячена питанню сучасного стану мікро-, малого та середнього підприємництва України з урахуванням наслідків уведених в останні роки протиепідеміологічних заходів. 32019 року весь світ перебуває в постійній соціально-політичній напрузі, яка вилилася у економічну кризу величезних масштабів, найменовану нині «коронакризою». У зв'язку із швидким поширення гострої респіраторної хвороби COVID-19, влада була вимушена ввести локдаун. У результаті майже кожна галузь промисловості та сільського господарства зазнала відчутних змін, які характеризуються як «занепад». Провівши аналіз актуальних нині фракторів, які перешкоджають розвитку малого та середнього підприємництва, авторами були виокремлені головні проблеми діяльності бізнес-структур в умовах пандемії COVID-19. Висвітлено сутність цисрровізації бізнесу, як одного 3 найдієвіших шляхів виходу з ситуації, що склалася.

Ключові слова: мале підприємництво, середнє підприємництво, коронакриза, карантин, цифровізація.
\end{abstract}

Статья посвящена вопросу современного состояния микро-, малого и среднего предпринимательства Украины с учетом последствий введенных в последние годы противоэпидемиологических мер. С 2019 года весь мир находится в постоянном социально-политическом напряжении, которое вылилось в экономический кризис огромных масштабов, именуемый ныне «коронакризисом». Из-за стремительного распространения острой респираторной болезни COVID-19, власти были вынуждены ввести локдаун. В результате почти каждая отрасль промышленности и сельского хозяйства претерпела ощутимые изменения, характеризующиеся как «упадок». Проведя анализ актуальных ныне фракторов, препятствующих развитию малого и среднего предпринимательства, авторы выделили главные проблемы деятельности бизнес-структур в условиях пандемии COVID-19. Освещена сущность цифровизации бизнеса, как одного из наиболее действенных путей выхода из сложившейся ситуации.

Ключевые слова: малое предпринимательство, среднее предпринимательство, коронакризис, карантин, цифровизация.

The article is devoted to the issue of the current state of micro, small and medium-sized businesses in Ukraine, taking into account the consequences for it of the anti-epidemiological measures introduced in recent years. The interest in this problem is due to the fact that it is small and medium-sized enterprises that represent the fundamental force for the constant economic growth of the state. These entities inherently have numerous advantages over large enterprises. Bearing on themselves a significant tax burden and forming a significant share of GDP, they increase their own importance in improving, first of all, the material and social components of the quality of life of the population. The article analyzes the dynamics of the number of operating small and medium-sized enterprises over the past 10 years. Changes in the number of employees in business units of the studied organizational and legal forms for the same period of time are considered. Since 2019, the whole world has been in constant socio-political tension, which has resulted in an economic crisis of enormous proportions, now referred to as the "coronacrisis". Due to the rapid spread of the acute respiratory disease COVID-19 caused by the SARS-CoV-2 coronavirus, the au- 
thorities were forced to make instant decisions. They are displayed in the introduction of the lockdown and the whole set of quarantine restrictions. As a result of their implementation, almost every branch of industry and agriculture has undergone tangible changes, which are more characterized as "decline". At the same time, the areas for which quarantine, on the contrary, became the impetus for the transition to a better level of running their own business, were identified. After analyzing the factors hindering the development of small and medium-sized businesses in Ukraine, the authors identified the main problems of the activities of business structures in the context of the COVID-19 pandemic. In addition, attention was paid to the search for tools to improve the situation of small and medium-sized businesses in Ukraine. In particular, it was established that there is a system of support from the state for economic units affected by quarantine. The essence of business digitalization is stated as one of the most effective ways out of the current situation.

Keywords: small business, medium business, corona crisis, quarantine, digitalization.

Постановка проблеми. На сьогоднішній день розвиток бізнесу, зокрема малого та середнього, має займати пріоритетну позицію серед стратегічних напрямків ведення державної політики України у секторі економіки. Адже варто зауважити, що мікро-, мале та середнє підприємництво (далі - МСП) забезпечує більш ніж 50-60\% ВВП країни й левову частку податкових надходжень. При цьому надаючи населенню величезну кількість робочих місць. За даними Державної служби статистики України вагому частку серед сукупної кількості вітчизняних підприємств у 2020 році становило саме МСП. Зокрема, у конкретних значеннях чисельність середніх підприємств становила 17946 од. (0,91\% від загальної кількості), малих - 56217 од. (2,85\%), мікро 1898902 од. (96,22\%). При цьому великі підприємства займали лишень 0,03\%, що рівнялось 512 одиницям.

Для Уряду України першочерговим завданням є розвиток підприємництва, це закріплено навіть в Угоді про асоціацію України з Європейським Союзом (Угода про асоціацію з ЄС) $[1$, с. 8]. Та не дивлячись на це, нині вітчизняний бізнес переживає надзвичайно складні часи. Останнє спричинене як посиленням існуючих раніше проблем підприємницького сектору, так і розвитком нових загроз, зумовлених пандемією COVID-19 та введенням відповідних протиепідеміологічних обмежень. Усе це призводить до необхідності проведення дослідження сучасного стану суб'єктів підприємництва, особливо МСП, виокремлення головних проблем і визначення перспектив сталого зростання бізнесу в умовах загострення коронокризи [2, с. 17].

Аналіз останніх досліджень і публікацій. Проблематика існування та впливу запровадження протиепідеміологічних карантинних заходів на діяльність суб'єктів мікро-, малого та середнього підприємництва сьогодні набула особливої актуальності. Вивченням даного питання займалися вітчизняні науковці, серед яких: М. Окландер, О. Шраменко, В. Онищенко, А. Ворфоломеєв, Н. Фролова [2], Р. Шевченко-Перепьолкіна [7], В. Дикань, 3. Двуліт, А. Завербний, А. Романюк [10] та інші.

Не дивлячись на те, що Україна та світ у цілому уже не перший рік фрункціонують в умовах пандемії, спричиненої коронавірусом SARS-CoV-2, на нашу думку, чимало питань пов'язаних з визначенням інструментів нівелювання наслідків коронакризи $€$ нерозкритими та потребують їх подальшого дослідження.

Формулювання цілей статті. Дослідження сучасного стану суб'єктів підприємництва в період пандемії, викликаної COVID-19, та визначення шляхів розвитку українського бізнесу в умовах коронакризи.

Виклад основного матеріалу дослідження. У наш час, розглядаючи трактування економічної сутності категорії «мале підприємництво», економічна література найчастіше ототожнює його безпосередньо з підприємництвом у цілому, або ж окремим об'єктом малим підприємством чи самостійно фрункціонуючим суб'єктом господарювання [3]. Ведення саме малого та середнього підприємництва має ряд переваг. Відтак, підприємства зазначеного виду досить швидко здатні адаптуватися до змін кон'юнктури ринку, різного роду економічних та політичних трансформацій в країні. Суб'єкти господарювання на максимальному рівні реагують на появу та зміну споживацьких потреб, тому що їх діяльність у більшості випадків відбувається в серері послуг, і відповідно комфорт життя населення залежить від кості їх роботи. Фактично фрірми МСП визначають швидкість економічного розвитку, структуру і якісні характеристики ВВП. Суб'єкти МСП надають країні змогу «заощадити» на соціальних виплатах по безробіттю, на створенні й облаштуванні нових робочих місць. Середній та малий бізнес фрормують більшу частину середнього класу. При цьому соціологічні дослідження показують, що країни з переважанням середнього класу мають 
більш стабільну фрінансову систему та економіку загалом. Уважається, що чим більший середній прошарок, тим більше податкових та неподаткових доходів спрямовуватиметься до державного бюджету та фрондів соціального страхування [4].

Отже, мале та середнє підприємництво відіграє неоціненне значення у розвитку сучасної економіки змішаного типу. До показників важливості ролі МСП можна віднести дані про динаміку його зростання (кількість діючих підприємств, зайнятість населення на підприємствах даного сектору, частка у ВВП і т.д.) і кількісні параметри класифрікації [3]. 3 урахування мінливості сьогоднішньої економічної ситуації в Україні, особливу увагу звернемо на зміни кількості малих (рис. 1) і середніх підприємств (рис. 2).

Таким чином, ми бачимо, що для малого підприємництва $€$ характерним значне кіль- кісне переважання над господарюючими суб'єктами середніх та великих фрорм. Спостерігається більш активна динаміка змін чисельності, умовно виокремимо два періоди, а саме 2010-2015 та 2015-2020 роки. У той же час лінія кількості середніх підприємств має сталу, менш хвилеподібну, тенденцію розвитку.

Говорячи про умови ведення господарської діяльності в Україні, то для представників мікро-, малого та середнього підприємництва вони постійно відзначалися наявністю соціально-економічних проблем. Теперішня ситуація пов'язана 3 подоланням третьої хвилі економічної кризи 2014 року у зв'язку з військовим конфрліктом на сході країни, анексією Криму, і зараз визначається переважаючою позицією сектору МСП в економіці $[1$, с. 8].

У цілому різноманітні дослідження свідчать про неоднозначність сподівань бізнесу у 2020 році. Інститут економічних досліджень

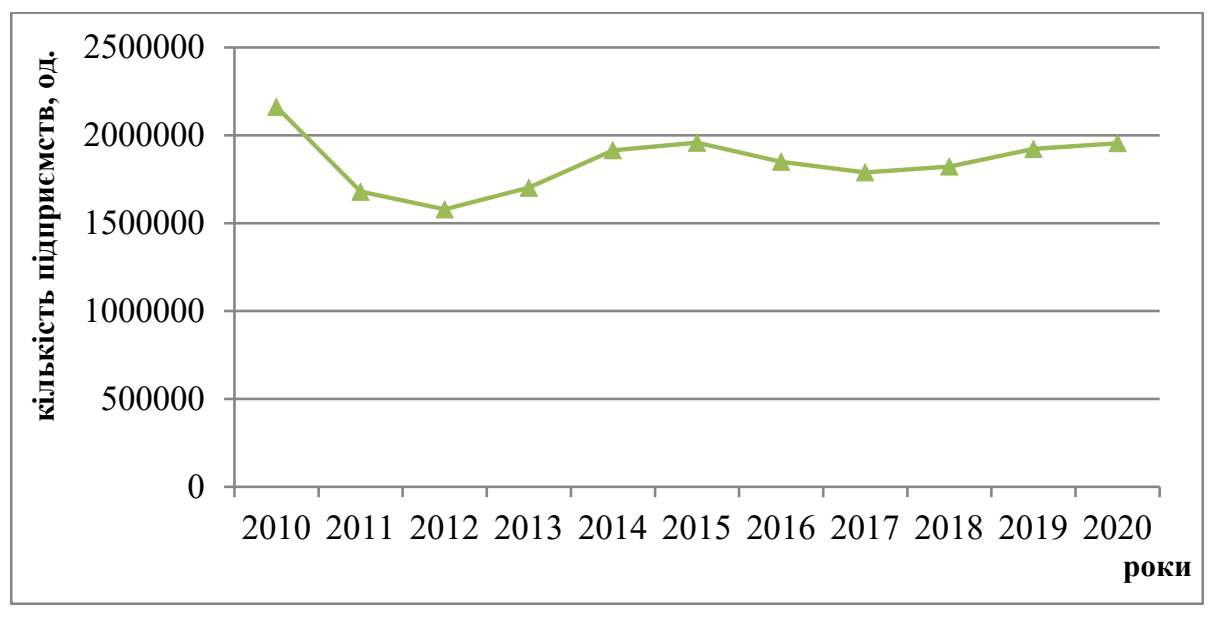

Рис. 1. Динаміка кількості малих підприємств, у тому числі мікро, в Україні

Джерело: складено автором на основі [5]

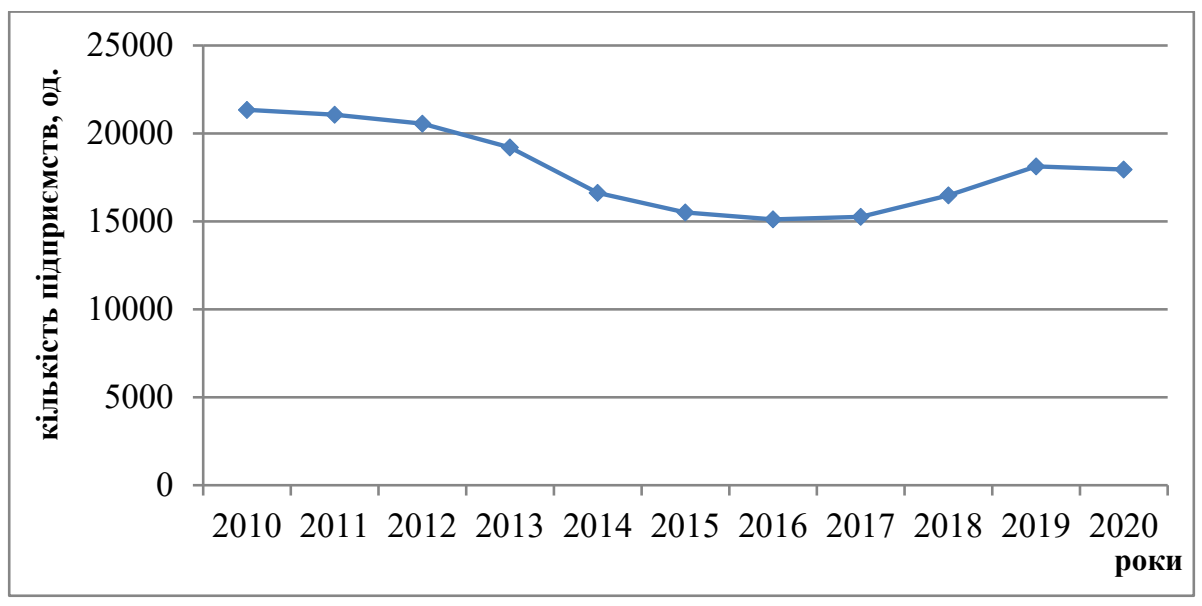

Рис. 2. Динаміка кількості середніх підприємств в Україні Джерело: складено авторам на основі [5] 
та політичних консультацій стверджує, що загалом сьогодні зростає рівень невпевненості бізнесу в майбутньому.

Що стосується проблем, 3 якими зіткнулися підприємці в 2020 році, під час пандемії COVID-19, то у першу чергу відбулося посилення «традиційних» труднощів: низький попит, проблеми з ліквідністю, відчутний конкурентний тиск, надмірне оподаткування, несприятливе нормативно-правове середовище та проблеми 3 енергопостачанням. Зокрема, малі та мікропідприємства скаржилися на «низький попит» - 77,3\%, «проблеми 3 ліквідністю» - 72,7\% і «високий рівень конкуренції» - 61,0\%. Представники середнього підприємництва також були незадоволеними низьким попитом $(69,3 \%)$ і проблемами 3 ліквідністю $(68,2 \%)$ [6, с. 22-23].

Відповідно до результатів опитування Європейської бізнес-асоціації, станом на 27.04.2020 р. в Україні через протиепідемічні обмеження призупинили свою діяльність 277 тис. підприємців. Разом 3 цим значного скорочення зазнала і пропозиція працевлаштування. Зокрема, на початку локдауну на сайті Work.ua було опубліковано 54072 вакансії, станом на 19 квітня 2020 тільки 18390. Аналізуючи динаміку кількості працевлаштованих на підприємствах в Україні (рис. 3) можна стверджувати, що в період 2018-2020 років спостерігається зниження кількості найманих робітників на великих і малих (у тому числі мікро) підприємствах, а для підприємств середнього сектору ситуація $€$ протилежною. Щоправда навіть у період карантину для сервісів онлайннавчання, віддаленої роботи, послуг з доставки товарів чи продажу товарів онлайн відкрилися додаткові можливості [7, с. 148-149].

у цілому на сьогоднішній день на 2022-2024 роки прогнозується прискорення економічного зростання економіки України. У тому числі позитивну динаміку мають й елементи попиту. Щодо рівня безробіття, до на допандемічний рівень $(8,2 \%)$ ми зможемо вийти лише у 2024 році.

Останні роки для нашої держави визначаються тим, що вона перебувала на стадії активного переформування законодавчої бази, маючи при цьому хоча б мінімально допустимі матеріальні ресурси та певний більш-менш стабільний імідж на міжнародній арені. Однак пандемія COVID-19 та необхідність запровадження локдауну внесли власні корективи в даний процес. Саме карантин значною мірою вичерпав майже усі наявні ресурси країни, а не підтримка карантинних норм населенням на належному рівні чи відсутність контролю дотримання цих норм з боку уряду, що посприяло появі недовіри $€ С$ до України, як потенційного члена співтовариства. За одним із існуючих прогнозів нашій державі не вдасться повернути власний потенціал менш ніж за три роки, адже наразі активних обертів набуває фріскалізація малого та середнього підприємництва. До того ж варто враховувати, що ВВП України почав падати ще до початку пандемії, що власне свідчить про неефрективність такої фріскальної політики [8, с. 12].

Звісно ж варто звернути увагу на те, що у таких складних умовах уряд здійснював підтримку бізнес сектору. Була запроваджена ціла система, яка складалася з різних елементів: кредитні канікули, податкові пресререн-

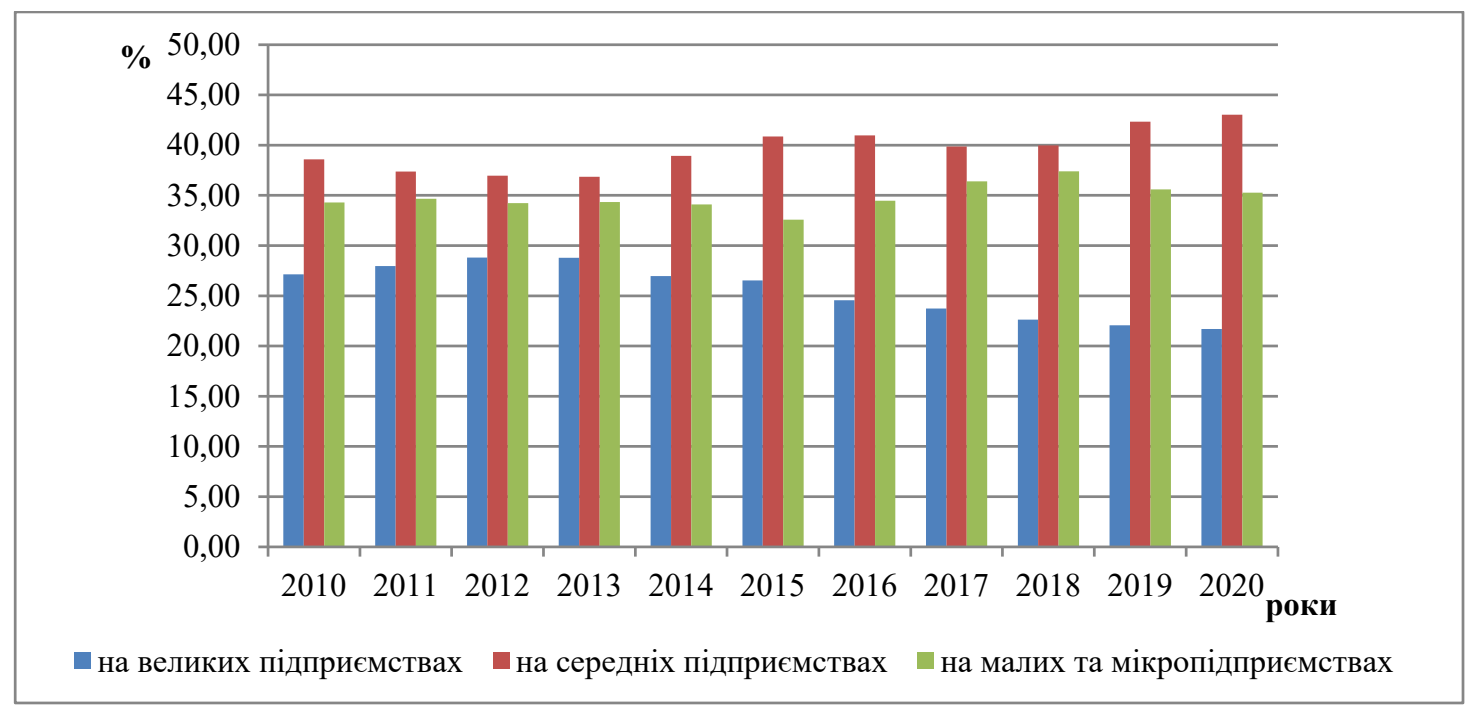

Рис. 3. Динаміка кількості найманих працівників у суб'єктів господарювання в Україні Джерело: складено автором на основі [5] 
ції, цільова підтримка малого, середнього та агробізнесу, інсрормаційна підтримка суб'єктів господарювання [9].

3 огляду на усе вище зазначене можна сказати, що нині єдиним рішенням для бізнесу $є$ переорієнтація на онлайн-сореру та швидка адаптація до неї. Для підготовки підприємницького середовища до переходу в онлайн пропонується здійснити три етапи:

1) аналіз і оптимізація бізнес-витрат (пошук нових ділових партнерів, постачальників і оптимізація несуттєвих витрат зважаючи на нові умови);

2) впровадження змін у трудовому колективі (надання переваги віддаленій формі роботи якщо це дозволяє специсріка діяльності фрірми, розроблення нових систем винагород і бонусів для співробітників, розрахунок нових ключових показників ефективності (KPI), перерозподіл обов'язків та повноважень керівників відділів);

3) адаптація до нових продуктів або послуг відповідно до потреб споживачів (в умовах карантину зосередити увагу на найбільш необхідних продуктах, розвинути більш вагомі переваги в порівнянні з конкурентами і підвищити пізнаваність бренду за рахунок уведення безкоштовної доставки, нових рекламних проєктів та онлайн-підтримки клієнтів) [10].
Наслідком існування введених карантинних обмежень в Україні стало зниження ВВП, зниження щомісячного доходу домашніх домогосподарств, збільшення частки безробітних у сорері зайнятості, зростання заборгованості домогосподарств [11, с. 19]. Цифрровізація ведення бізнесу стане однозначно неминучою подією, а не просто модною тенденцією. Однак розроблення власного сайту або інтернет-магазину $\epsilon$ лише початковою стадією виходу в онлайн. Останнє повинне підкріплюватися фрормуванням чіткої маркетингової стратегії, розумінням пошукової оптимізації, трафріку, запуску реклами, підтримки клієнтів тощо

Висновки. Економічна криза, викликана пандемією COVID-19, здійснила серйозний негативний вплив як на світову, так і на економіку України. Фахівці схиляються до думки, що ії наслідки будуть відслідковуватися ще досить тривалий період часу. Нині держава покладає великі надії безпосередньо на малі та середні підприємства щодо якнайшвидших і позитивних зрушень в структурі економіки, позбавлення від економічної кризи та фрормування міцного підґрунтя для подальшого економічного зростання. В умовах, що склалися, єдиним рішенням для бізнесу є переорієнтація на онлайн-сореру та швидка адаптація до неї.

\section{СПИСОК ВИКОРИСТАНИХ ДЖЕРЕЛ:}

1. Business OMBUDSMAN council. Великі проблеми малого бізнесу: системний звіт. Березень 2020 р. С. 64. URL: https://boi.org.ua/media/uploads/system_bigproblemssmalbusiness/3_2020_system_ua.pdf

2. Фролова Н. Л. Сучасний стан і перспективи розвитку малого та середнього бізнесу в Україні в умовах коронакризи. Інвестиції: практика та досвід. 2021. № 19. С. 16-21. URL: http://www.investplan.com.ua/ pdf/19_2021/5.pdf

3. Красота О. В., Кір'єв І. С. Особливості розвитку малого підприємництва в умовах порушення макроекономічної стабільності. Ефрективна економіка. 2021. № 2. URL: http://www.economy.nayka.com.ua/pdf/2_2021/100.pdf

4. Національна Асоціація Адвокатів України. Малий бізнес в умовах пандемії COVID-19: правове регулювання фрінансової підтримки державою. 19 серпня 2020. URL: https://unba.org.ua/publications/print/5792-malijbiznes-v-umovah-pandemii-covid-19-pravove-regulyuvannya-finansovoi-pidtrimki-derzhavoyu.html

5. Державна служба статистики України. Кількість діючих суб'єктів великого, середнього, малого та мікропідприємництва за видами економічної діяльності у 2010-2020 роках. URL: http://www.ukrstat.gov.ua/operativ/ menu/menu_u/sze_20.htm

6. Бураковський І., Юхименко С., Коссе І., Кравчук В. Державна підтримка активності в період пандемії КОВІД-19: регіональний вимір: аналітична доповідь. ГО "Інститут економічних досліджень та політичних консультацій". 2021. C. 74. URL: http://www.ier.com.ua/files/publications/Special_research/2021/covid19_report_final1.pdf

7. Шевченко-Перепьолкіна P.I. Шляхи розвитку малого бізнесу в умовах COVID-19. Iндраструктура ринку. 2020. Вип. 49. С. 147-151. URL: http://www.market-infr.od.ua/journals/2020/49_2020_ukr/28.pdf

8. ЮНІСЕФ Україна. Консенсус-прогноз «Україна: вплив COVID-19 на економіку і суспільство». Серпень 2020. № 52. URL: https://www.unicef.org/ukraine/documents/consensus-report

9. Міністерство охорони здоров'я України : веб-сайт. URL: https://covid19.gov.ua/prohramy-pidtrymky-biznesu

10. Двуліт 3.П., Завербний А.С., Романюк А.О. Диджиталізація - дієвий інструмент антикризового розвитку бізнесу в умовах пандемії. Ефективна економіка. 2021. № 1. URL: http://www.economy.nayka.com.ua/ pdf/1_2021/7.pdf 
11. Лавров Р. В., Кравченко А. О., Козловський С. В., Мазур Г. Ф. Тенденції та перспективи розвитку економіки України в умовах коронакризи. Економіка та держава. 2021. № 10. C. 12-19. URL: http://www.economy.in.ua/ pdf/10_2021/4.pdf

\section{REFERENCES:}

1. Business OMBUDSMAN council (March 2020) Big problems of small businesses: a system report, no. 64. Retrieved from: https://boi.org.ua/media/uploads/system_bigproblemssmalbusiness/3_2020_system_ua.pdf (in Ukrainian)

2. Frolova N. (2021) Current state and prospects of development of small and medium-sized businesses in Ukraine in the context of the coronavirus crisis. Investytsiyi: praktyka ta dosvid, 19, 16-21. Retrieved from: http://www.investplan.com.ua/pdf/19_2021/5.pdf (in Ukrainian)

3. Krasota O., Kiriev I. (2021) Features of small entrepreneurship development under macroeconomic stability violations. Efektyvna ekonomika, no. 2. Retrieved from: http://www.economy.nayka.com.ua/pdf/2_2021/100.pdf (in Ukrainian)

4. Ukrainian National Bar Association (August 19, 2020) Small businesses in the context of the COVID-19 pandemic: legal regulation of financial support by the state. Retrieved from: https://unba.org.ua/publications/ print/5792-malij-biznes-v-umovah-pandemii-covid-19-pravove-regulyuvannya-finansovoi-pidtrimki-derzhavoyu.html (in Ukrainian)

5. State Statistics Service of Ukraine. Number of active entities of large, medium, small and micro-entrepreneurship by type of economic activity in 2010-2020. Retrieved from: http://www.ukrstat.gov.ua/operativ/menu/menu_u/ sze_20.htm (in Ukrainian)

6. Burakovskyi, I. Yukhymenko, S. Kosse, I. and Kravchuk, V. (2021) State support for activity during the COVID-19 pandemic: a regional dimension, NGO "Institute for Economic Research and Policy Consulting", no. 74. Retrieved from: http://www.ier.com.ua/files/publications/Special_research/2021/covid19_report_final1.pdf (in Ukrainian)

7. Shevchenko-Perepolkina R. (2020) Ways of small business development in COVID-19. Market Infrastructure, 49, 147-151. Retrieved from: http://www.market-infr.od.ua/journals/2020/49_2020_ukr/28.pdf (in Ukrainian)

8. UNICEF Ukraine (August 2020) Consensus forecast «Ukraine: the impact of COVID-19 on the economy and society», no. 52. Retrieved from: https://www.unicef.org/ukraine/documents/consensus-report (in Ukrainian)

9. Ministry of Health of Ukraine: Official web-site. Retrieved from: https://covid19.gov.ua/prohramy-pidtrymkybiznesu (in Ukrainian)

10. Dvulit Z., Zaverbnyi A., Romaniuk A. (2021) Digitalization - an effective tool for anti-crisis business development in a pandemic. Efektyvna ekonomika, 1. Retrieved from: http://www.economy.nayka.com.ua/pdf/1_2021/7.pdf (in Ukrainian)

11. Lavrov R., Kravchenko A., Kozlovskyi S., Mazur H. (2021) Trends and prospects for the development of ukraine's economy in the coronavirus crisis. Ekonomika ta derzhava, 10, 12-19. Retrieved from: http://www.economy.in.ua/pdf/10_2021/4.pdf (in Ukrainian) 